\title{
A Study of Determination in Chinese Peasant Workers' Wage: The Role of Human Capital and Market Segmentation
}

\author{
Hengyou Sun \\ Economic School, Huazhong University of Science \& Technology \\ Wuhan 430074, China \\ Tel: 86-135-0384-6375 E-mail: hysun1@163.com
}

Received: May 3, 2012

Accepted: May 22, 2012

Published: July 15, 2012

doi:10.5430/ijba.v3n4p31

URL: http://dx.doi.org/10.5430/ijba.v3n4p31

\begin{abstract}
The result of OLS estimation indicates that peasant workers' wage will increase by about $6.1 \%$ when education increases 1 year, and the wage increase of those who experienced professional training is about $15.7 \%$ more than those who not. After controlling other variables, industry monopoly not only brings minority's prosperity but also majority's poverty. Both human capital effect and labor market segmentation effect are enhanced obviously by Chinese marketization process. The conclusions imply that strengthening education and training and eliminating labor market segmentation will be very important policy to improve peasant workers' wage. This paper also finds that none of the years of parental schooling, the numbers of brothers and sisters and the types of investigated area is an ideal IV when dealing with endogenous educational issues.
\end{abstract}

Keywords: Peasant worker, Wage, Human capital, Market segmentation

\section{Introduction}

The term "urbanization" in economics has a very rich content, but in current Chinese situation, the first question for peasant workers is how to urbanize them into townspeople, The elements will affect peasant workers' urbanization process, which include whether urbanization development provides enough jobs, whether the construction of the labor market allows the sufficient flow of labor resources, and whether social security system can achieve the goal of fair treatment to peasant workers who work in cities. Purely from the angle of individuals, the core of urbanization for farmer workers is whether they can obtain sufficient income to meet the ever-improving life standard of living city or not. It is an in-depth study of peasant workers' urbanization, here are the further questions: what factors determine wages of peasant workers and to what extent?

\section{Literature Review}

What factors determine the laborer salary income level? Previous literature on this can be grouped into two, namely individualism and structuralism (Sakamoto Arthur, 1988). Individualism stresses determining role of human capital on wage, there is a strong correlation between human capital factors, including educational background, work experience and professional training, to the labor productivity, i.e. divergence in wage income is the compensation for investing cost difference in human capital. Structuralism criticizes the individualism's perfect competition assumptions and lack of evidence, and emphasizes the decisive role of the structural variables on wage income, that the perfect competitive labor market does not exist in reality, the factors leading to labor market segmentation often weakens market forces effect, the final play of human capital performance and assessment of human capital value from entrepreneurs depend on various departments' specific production mode, organizational structure and average labor productivity, and is subject to specific protection mode of different labor market sectors (Lewirr Epstein, Noah, Moshe Semynonv, 1994). Although large body of evidence supports structuralism (Gerber, Theodore of P., 2002, Zang Xiaowei, 2002), more empirical studies show that the role of human capital and market segmentation cannot be ignored in determining labor income.

Which factor, human capital or structure, plays a greater decisive role on wage income? Different answers to this question imply completely different policies: if human capital plays a more important role, then macroscopic policy should promote education and training investment; otherwise, if structure, such as market segmentation plays a greater decisive role, then development of the labor market is not perfect, and the measures aiming at the elimination of labor market segmentation of great importance. Existing research does not draw the same conclusion (Bibb, Robert and 
William H. Form, 1997, Lord III, George and William W. Falk, 1980). The difference in conclusions may due to different research methods, or divergent samples, which develop at different degrees in the labor market. All make the research of Chinese peasant worker market more important. Till now, there is few specific study has been done on this group: peasant workers in China.

Whether marketization will weaken the role of structural factors to improve farmer workers group's yield rate of human capital or not? Some studies show, with the development of marketization, effect of structural factors may decline and yield rate of human capital may gradually rise (Nee Victor, 1991); however, others indicate, in the process of marketization, on the one hand, political forces may change into the social network capital and then into private assets (Rona-Tas \& Akos, 1994); on the other hand, the public power will derive some of the political elites' rent-seeking ability which may affect distribution results (Liu Xin, 2003), thus the yield of structural factors and other non-market forces will never reduce. From the existing researches, the role of marketization on human capital and market segmentation is still an open issue for further study.

\section{Description of Data and Statistics}

The data is from General Social Survey of 2006, co-hosted by Department of Sociology, People's University of China, and Ministry of Social Sciences, Hong Kong University of Science and Technology. The survey included two questionnaires: rural and urban areas, which cover 28 provinces, such as Beijing, Tianjin, autonomous regions and municipalities, from which they got 10151 samples in total. Due to the objectives, the samples are filtered by three conditions, such as agricultural registered permanent residence, current work, and employee with or without fixed employer, to ensure the objects of this research are farmer workers working in cities. After making up for the missing values of some variables with interpolation, the final samples for analysis are 722 in total. As for industry division, we take Zhang's (2004) industry classification as reference. Mining industry, manufacturing, construction, wholesale and retail trade, catering industry, social services are designated as open industry, which is valued 0. Different from Zhang (2004), we put transportation, storage, post and telecommunication industry and other industries into monopoly industry, which is valued 1. Taking the fact that industry segmentation is the main form of China's current labor market segmentation into account, we introduce industry variables as the agent of labor market segmentation into the model. As for parental years of education, scaling measures are adopted for convenience in analysis, and conversion is done according to the following criteria: illiterate $=1$; primary school $=6$; junior school $=9$; senior, vocational and secondary school, technical school $=12$; adult secondary, college $=15$; adult undergraduate, undergraduate $=16$; graduate or above $=19$. On wage variable, we use wages of last month in CGSS survey, so the samples only reflect wage income, but do not include the operating income. Description and statistical characteristics of various variables are shown in table 1 and table 2 as follows.

$<$ Table 1 about here>

$<$ Table 2 about here $>$

\section{Model Analysis}

The theoretical circles commonly explain the wage determination with Mincer equation, whose explained variable is logarithm of wage, whose explanatory variables are education, work experience and experience squared. The reason why experience and experience squared can come into the model is, that Mincer and other literature on human capital agree that the term on-the-job training in human capital theory is mainly from experience, and it may have nonlinear effect on wage income. Learning at work, as an assumption to improve the productivity based on no cost, however, is not a good description in the labor market with a wide range of labor mobility (Zeng, 2006:128). Because of the characteristics of Chinese farmer workers--high flowing frequency, vocational training is added as a variable in the model. Also, we add an industry as dummy variable in order to investigate the influence of labor market segmentation on farmer workers' wages.

Estimating the rate of human capital's return with Mincer equation involves two important issues: one is heterogeneous ability of human (Griliches, 1977), which means if there is a positive correlation between individual ability and education, training, then it possibly leads to overestimation on rate of human capital's return of human capital. In order to overcome this problem, this model in this study controls individual characteristics which may reflect identity, such as gender, age, marital status, and Party membership. In addition, it still controls the variables reflecting family background, such as number of family members, Father's years of education, mother's years of education, which may affect their children's opportunity to receive education (Yao, Huang \&Su, 2006).

The other is endogeneity of education (Heckman J., L. Lochner and P. Todd, 2003). Within regression techniques, the commonly used method dealing with it is to find an instrumental variables serving education, i.e. using second-order 
regressive model substitute least squares (LS) estimation method, such as parental years of education, number of brothers and sisters (Wooldridge, 2003), the quarter born at (Angrist J. D. and A. B. Krueger, 1991a), distance from the birth place to university (Card, 1995), and elementary school site (Wang, Cai \& Zhang, etc., 2008). However, after applying three instrumental variables into this study, such as parental years of education, number of brothers and sisters and types of investigated regions, it finds out none of them is significant at the first-order regression. In fact, previous studies show, as for whether these variables are effective, there is always controversy in theoretical circles: family background may correlate to error term, but it is not a good instrumental variable (Conneely K. and R. Uusitalo, 1999); quarter born at may have something with elements affecting wages (Bound J., D. A. Jaeger and R. M. Baker, 1995); after controlling more variables, there may be absolutely no error in ability omissions in the wage equation (Angrist J. D. and A. B. Krueger, 1991b). Therefore, this study gives up on two-order regression method, and adopts least squares (LS) estimation method, estimated results shown in table 3 equation (1).

$<$ Table 3 about here $>$

From the equation (1), the $\mathrm{P}$ of $\mathrm{F}$ statistics is all 0 , showing that whole model fitting is good. Experience, the square of experience and father's years of education, these three variables are not significant; while the average significance level of other variables is within 5\%, except age whose significance level is $10 \%$. In human capital factors, the coefficient of education is 0.06103 , which means salary of peasant workers increase by about $6.1 \%$ if their formal education increases one year; Training coefficient is 0.15721 , which means peasant workers who participate in training may get more salary $15.7 \%$ higher than those not. Experience and square of experience are not significant, this may be due to high flowing frequency of farmer workers, and their experience in previous work can't help to improve productivity effectively.

The coefficient of industry variable is -0.20685 , which indicates that China's labor market is indeed segmented by industry and this division's influence on the wages of farmer workers cannot be ignored. It is worth noting that the coefficient of industry variable's influence on farmer workers' wages is minus, which means that the farmer workers entering the monopoly industry get lower wages than those who enter the competitive industry. This seems contrary to the conclusions of economic theory and empirical research, which in general consider that monopolists in product market usually set entry barriers in the labor market, so they turn high monopoly profits into high income of the small number of people in this industry. But the real situation may be that there are divergent internal labor employment system existing in most of monopoly firms in China, for instance, formal workers, contract workers and temporary workers, they have great difference in wage income. Though contract and temporary workers do the same work, even harder or more tiring work than official or formal workers, they cannot share the high profits of the firms. Within the monopoly industry, there are two labor markets, formal and informal, and the majority of the peasant workers in monopoly industry work in the informal labor market. To test the reasonability of this interpretation, samples are firstly divided into monopoly industry and competitive industry, and then simply get the average of wages of these two industries, results show the average salary of farmer workers in monopoly industry is about 948 RMB; while the average of those in competitive industry is about $1102 \mathrm{RMB}$. It firstly proves that farmer workers in monopoly industry do have been paid lower than those working in competitive industry. Secondly, the least squares estimation is adopted respectively after the model has been divided into two: monopoly and competitive, and it finds out return rates on education of these two are 0.0167 and 0.07496 , i.e., the rate of return on education in competitive industry is 4.5 times of that in monopoly industry. This shows that monopoly industry is not only creating high-income myth of small number of people beyond the stage of economic development, and also build a low-wage trap of the majority departing from social harmony, which also is another evidence of the income inequality caused by the internal segmentation of labor market industry and trade monopolies.

Other explanatory variables in equation (1) are also quite interesting; such as age, which has significant negative impact on wage income, due to the fact that the work farmer workers do mainly relate to physical labor, which decreases gradually with the growing of age. Chinese communist party members' income are lower than non-party members, the reason might be those party members shoulder more public affairs when they work, thus, they get less paid. Gender also deserves special attention, male get paid 37 percent more than female. Suppose male's average wage is 1000 RMB, and then female only gets average $630 \mathrm{RMB}$, one cannot survive in cities with such income. Therefore, it can be seen as one kind of severe gender discrimination.

From explanation of the model, if industry variables are removed from equation (1), then it turns out to be equation (2), in which the adjusted $R^{2}$ declines to 0.22527 ; if four human capital variables, such as education, experience, and squared experience and training, we get equation (3), in which the adjusted $R^{2}$ declines to 0.17050 . It seems that human capital plays more important role in determining farmer workers' wages. However, if we merely remove education from equation (1), the adjusted $R^{2}$ is 0.18859 ; if we only remove the training, its adjusted $R^{2}$ is 0.22936 , 
generally quite equal to that in equation (2). At least, it indicates labor market segmentation and vocational training have similar effect on wage determination. Thus, it is equally important to eliminate labor market segmentation and to increase vocational training of farmer workers in raising famer workers' wages.

In order to investigate effects of human capital and market segmentation on marketization, we create equation (4) and equation (5) by applying the least squares estimation to samples respectively, which have been divided into east and Midwest. Market-oriented does really enhance the return rate of human capital. For instance, coefficient of education is 0.07146, which is 4.28 times of that (0.01670) in equation (5). Coefficient of training in the both equations are roughly the same, the Midwest is a little higher than the east. In addition, impact of industry segmentation on wage income is also expanding with the development of marketization, as data show, coefficient of industry variable in equation (4) is -0.26422 , which is about $80 \%$ higher the absolute value of that in equation (5). All that indicates it is a further strengthening trend that China's labor market is segmented according to industry during the process of marketization.

\section{Conclusions and Implications to Policy}

This study emphasizes the impact of human capital and industry segmentation on farmer workers' wage and quality of employment, and the results show education and training have a significant positive impact on it. After controlling other variables, peasant workers' wage will increase by 6.1 percent when year of education increases by one year; the wage of trained workers is $15.7 \%$ higher than not trained. Also, as marketization process deepens, education and training have increasingly significant impact on wage income. On the other hand, industry segmentation has a significant negative impact on the wages of migrant workers, and workers in monopoly industry get much lower pay than those in competitive industry. Therefore, monopoly industries not only create a small number of wealthy people, also contribute to the poverty of the majority of people, marketization strengthens the negative effect of labor market segmentation according to industry on peasant workers' wage.

This study further proves importance of education investment in human capital, especially basic education and training in order to improve farmer workers' wages. At the same time, the force of marketization is limited, and any hope of automatically eliminating monopoly powers by deepening marketization reforms is impractical. In fact, in order to raise farmer workers' wages and improve their quality of life, we have to enhance legislation and law enforcement efforts, and further weaken the role of the executive power in the allocation of resources resulting labor market division according to industry, especially make explicitly in law it illegal that adopting different employment system within the same industry and the same enterprise, to force monopoly industries shoulder greater social responsibility by promoting the employment of farmer workers.

\section{References}

Angrist J. D., \& A. B.Krueger. (1991). Does Compulsory School Attendance Affect Schooling and Earnings? Quarterly Journal of Economics, 979-1014. http://dx.doi.org/10.2307/2937954

Bibb Robert, \& William H. Form. (1997). The Effects of Industrial Occupational and Sex Stratification on Wages in Blue-collar Markets. Social Forces, 55(4), 974-996

Bound J., D. A. Jaeger, \& R. M. Baker. (1995). Problems with Instrumental Variables Estimation When the Correlation between the Instruments and Endogenous Explanatory Variables are Weak. Journal of the American Statistical Association, 443-450.

Card D. (1995). Using Geographic Variation in College Proximity to Estimate the Return to Schooling. In L. N. Christophe's, E. K. Grant and R. Swidinsky (Eds.), Aspects of Labor Market Behavior: Essays in Honor of John Vanderkamp. Toronto: University of Toronto Press.

Conneely K., \& R. Uusitalo. (1999). Estimating Heterogeneous Treatment Effects in the Becker Schooling Model. Mimeo, University of Helsimki.

Gerber Theodore P. (2002). Structural Change and Post-socialist Stratification Labor Market Transitions in Contemporary Russia. American Sociological Review, 67(5), 629-659. http://dx.doi.org/10.2307/3088910

Griliches. Z. (1977). Estimation Returns to Schooling: Some Econometric Problems. Econometrics, 45(1), 1-22. http://dx.doi.org/10.2307/1913285

Heckman J., L. Lochner, \& P. Todd. (2003). Fifty Years of Mincer Earnings Regressions. NBER Working Paper. 9732

Jeffrey M. Wooldridge. (2003). Introductory Econometrics: A Modern Approach. Beijing: China Renmin University Press.

Lewirr Epstein, Noah, \& Moshe Semynonv. (1994). Sheltered Labor Markets, Public Sector Employment and 
Socioeconomic Returns to Education of Arabs in Israel. American Journal of Sociology, 100.

Liu, Xin. (2003). Market Transition and Social Stratification: theoretical debate focus and issues to be solved. Social Science of China, (5), 102-110.

Lord III George F., \& William W. Falk. (1980). An Exploratory Analysis of Individualist Versus Structuralist Explanations of Income. Social Forces, 59(2), 376-391.

Nee Victor. (1991). Social Inequalities in Reforming Sate Socialism: Between Redistribution and Markets in China. American Sociological Review, 56(3), 267-282. http://dx.doi.org/10.2307/2096103

Rona-Tas, Akos. (1994). The First Shall Be Last? Entrepreneurship and Communist Cadres in the Transition from Socialism. American Journal of Sociology, 100(1), 40-69. http://dx.doi.org/10.1086/230499

Sakamoto Arthur. (1988). Labor Market Structure, Human Capital and Earnings Inequality in Metropolitan Areas. Social forces, 67(1), 86-107

Wang, Dewen, Cai fang, \& Zhang Guoqing. (2008). Employment and wage determination of migrating rural labors: Importance of education and training. Economics, (4), 1131-1148.

Yao, Xianguo, Huang, Zhiling, \& Su, Zhenhua. (2006). Family background and return rate of education. China's Labor Economics, (4), 23-40.

Zang Xiaowei. (2002). Labor Market Segmentation and Income Inequality in Urban China. Sociological Quarterly, 43(1), 27-44. http://dx.doi.org/10.1111/j.1533-8525.2002.tb02382.x

Zhang, Zhanxin. (2004). Industry Segmentation of Labor Market and Flow of Labor Force. Journal of Chinese Population Science, (2), 45-52.

Table 1. Instructions of discrete variables and sample distribution

\begin{tabular}{|l|l|c|c|c|}
\hline Variables & description & code & frequency & percentage \\
\hline \multirow{3}{*}{ Gender } & male & 1 & 433 & 40 \\
\cline { 2 - 5 } & female & 0 & 289 & 60 \\
\hline \multirow{2}{*}{ Marital status } & married & 1 & 514 & 71.1 \\
\cline { 2 - 5 } & unmarried & 0 & 209 & 28.9 \\
\hline \multirow{2}{*}{ Party membership } & Chinese communist party members & 1 & 69 & 9.6 \\
\cline { 2 - 5 } & others & 0 & 653 & 90.4 \\
\hline \multirow{2}{*}{ Training } & trained & 1 & 213 & 29.5 \\
\cline { 2 - 5 } & Not trained & 0 & 510 & 70.5 \\
\hline \multirow{2}{*}{ Distribution of industries } & Monopoly industry & 1 & 180 & 24.9 \\
\cline { 2 - 5 } & Open or competitive industry & 0 & 543 & 75.1 \\
\hline \multirow{2}{*}{ Area } & East region & 1 & 375 & 51.9 \\
\cline { 2 - 5 } & Midwest region & 0 & 348 & 48.1 \\
\hline
\end{tabular}

Table 2. Statistical characteristics of the observed values of continuous variables

\begin{tabular}{|l|c|c|c|c|}
\hline Variables & Maximum & Minimum & Average & Standard deviation \\
\hline Age & 67 & 19 & 35.7 & 10.7 \\
\hline Years of education & 19 & 1 & 8.9 & 3 \\
\hline Work experience & 45 & 1 & 6.9 & 7.7 \\
\hline Wage & 9000 & 100 & 1063.6 & 945.4 \\
\hline Number of brothers and sisters & 10 & 1 & 3.7 & 1.9 \\
\hline Mother's years of education & 12 & 1 & 4.2 & 3.5 \\
\hline Father's years of education & 16 & 1 & 5.2 & 3.5 \\
\hline Number of family members & 9 & 1 & 2.4 & 1.1 \\
\hline
\end{tabular}


Table 3. Determination model of farmer workers' wages

\begin{tabular}{|c|c|c|c|c|c|}
\hline & $\begin{array}{c}\text { All the } \\
\text { samples } \\
\text { Equation (1) }\end{array}$ & $\begin{array}{l}\text { human capital } \\
\text { model } \\
\text { Equation (2) }\end{array}$ & $\begin{array}{l}\text { market segmentation } \\
\text { model Equation (3) }\end{array}$ & $\begin{array}{c}\text { Eastern } \\
\text { samples } \\
\text { equation (4) }\end{array}$ & $\begin{array}{l}\text { central and western } \\
\text { samples equation } \\
(5)\end{array}$ \\
\hline \multirow[t]{2}{*}{ Constant } & 6.21300 & 6.22687 & & 6.18288 & 6.25235 \\
\hline & $(0.00000)$ & $(0.00000)$ & & $(0.00000)$ & $(0.00000)$ \\
\hline \multirow[t]{2}{*}{$\begin{array}{l}\text { Years of } \\
\text { Education } \\
\end{array}$} & 0.06103 & 0.05767 & & 0.07146 & 0.04522 \\
\hline & $(0.00000)$ & $(0.00000)$ & & $(0.00000)$ & $(0.00047)$ \\
\hline \multirow[t]{2}{*}{ Work experience } & 0.01057 & 0.00804 & & 0.01955 & 0.00463 \\
\hline & $(0.25582)$ & $(0.38923)$ & & $(0.15802)$ & $(0.70808)$ \\
\hline \multirow[t]{2}{*}{$\begin{array}{l}\text { Squares of work } \\
\text { experience }\end{array}$} & -0.00037 & -0.00030 & & -0.00104 & -0.00003 \\
\hline & $(0.20481)$ & $(0.30506)$ & & $(0.02536)$ & $(0.93752)$ \\
\hline \multirow[t]{2}{*}{$\begin{array}{l}\text { Vocational } \\
\text { training } \\
\end{array}$} & 0.15721 & 0.12459 & & 0.15060 & 0.16988 \\
\hline & $(0.00495)$ & $(0.02474)$ & & $(0.04159)$ & $(0.03928)$ \\
\hline \multirow[t]{2}{*}{ Industry } & -0.20685 & & 6.90633 & -0.26422 & -0.14692 \\
\hline & $(0.00064)$ & & $(0.00000)$ & $(0.00130)$ & $(0.09226)$ \\
\hline \multirow[t]{2}{*}{ Gender } & 0.37088 & 0.37307 & 0.37831 & 0.26873 & 0.45577 \\
\hline & $(0.00000)$ & $(0.00000)$ & $(0.00000)$ & $(0.00010)$ & $(0.00000)$ \\
\hline \multirow[t]{2}{*}{ Age } & -0.00592 & -0.00619 & -0.01050 & -0.00276 & -0.00698 \\
\hline & $(0.07108)$ & $(0.06088)$ & $(0.00072)$ & $(0.04473)$ & $(0.02549)$ \\
\hline \multirow[t]{2}{*}{ Marital status } & -0.12879 & -0.13764 & -0.17865 & -0.04303 & -0.19952 \\
\hline & $(0.04905)$ & $(0.03672)$ & $(0.00775)$ & $(0.06581)$ & $(0.04186)$ \\
\hline \multirow[t]{2}{*}{ Party membership } & -0.27241 & -0.35393 & -0.20944 & -0.33442 & -0.24289 \\
\hline & $(0.00123)$ & $(0.00001)$ & $(0.01012)$ & $(0.00189)$ & $(0.06654)$ \\
\hline \multirow[t]{2}{*}{$\begin{array}{l}\text { Number of family } \\
\text { members }\end{array}$} & -0.04695 & -0.04735 & -0.04146 & -0.08262 & -0.01322 \\
\hline & $(0.03476)$ & $(0.03458)$ & $(0.07251)$ & $(0.00937)$ & $(0.06219)$ \\
\hline \multirow[t]{2}{*}{$\begin{array}{l}\text { Father's years of } \\
\text { education }\end{array}$} & 0.01242 & 0.01342 & 0.01784 & 0.02138 & 0.00874 \\
\hline & $(0.14476)$ & $(0.11760)$ & $(0.04374)$ & $(0.07816)$ & $(0.04886)$ \\
\hline \multirow[t]{2}{*}{$\begin{array}{l}\text { Mother's years of } \\
\text { education }\end{array}$} & 0.01746 & 0.01810 & 0.02330 & 0.01870 & 0.00008 \\
\hline & $(0.03729)$ & $(0.03209)$ & $(0.00748)$ & $(0.11023)$ & $(0.09462)$ \\
\hline \multirow[t]{2}{*}{ F statistics } & 19.64457 & 20.05831 & 22.17145 & 13.20782 & 7.86280 \\
\hline & $(0.00000)$ & $(0.00000)$ & $(0.00000)$ & $(0.00000)$ & $(0.00000)$ \\
\hline Adjusted R & 0.23682 & 0.22527 & 0.17050 & 0.28145 & 0.19226 \\
\hline Observations & 722 & 122 & 122 & 375 & 347 \\
\hline
\end{tabular}

Note: all the numbers in brackets are $\mathrm{P}$ value of corresponding variable $\mathrm{T}$ statistics 